\title{
基于自动特征提取方法的太阳耀斑预报模型
}

 \\ (1) 北京物资学院, 北京 101149 ; \\ (2) 中国科学院国家天文台, 北京 100012; \\ (3) 中国科学院空间科学与应用研究中心, 北京 100090 \\ * 联系人, E-mail: lirong@bao.ac.cn
}

2016-09-23 收稿, 2016-10-20 修回, 2016-10-21 接受, 2016-11-29 网络版发表

国家自然科学基金(11273031，11303051)、智能物流系统北京市重点实验室项目(BZ0211)和北京市智能物流系统协同创新中心项目资助

\begin{abstract}
摘要在太阳耀斑预报模型中, 首先需要从原始观测数据中提取刻画太阳活动区特性的物理特征参量, 然后使 用统计或机器学习方法寻找物理特征参量与太阳耀斑发生的关系，以达到建立太阳耀斑预报模型的目的。其中， 太阳活动区物理特征的提取在整个建模过程中发挥着重要的作用, 活动区物理特征的优劣直接决定着预报模型性 能的高低. 然而, 随着机器学习技术的发展, 机器学习方法中的深度学习算法能够从原始数据中自动提取特征, 并建立预报模型. 本文利用深度学习方法建立了一个太阳耀斑预报模型. 与先提取活动区物理参量、再建立预报 模型的传统机器学习方法相比较, 本文所建立的预报模型具有更好的预报性能.
\end{abstract}

关键词太阳耀斑, 太阳活动区, 磁场特征, 机器学习

太阳耀斑源于太阳大气中磁能的突然释放，与 耀斑相关的高能粒子加速和辐射增强可能会产生一 系列灾害性空间天气事件, 例如, 威胁宇航员的安 全、影响通讯质量、降低全球定位系统的精度等. 因 此太阳耀斑预报是太阳物理和空间天气领域持续关 注的重要问题.

到目前为止, 已有许多统计的和机器学习的方 法被用于建立太阳耀斑预报模型. 利用这些方法建 立太阳耀斑预报模型通常包含两大步: (1) 提取活动 区的物理参量; (2) 建立活动区物理参量与太阳耀斑 发生之间的联系.

在活动区特征提取方面, McIntosh ${ }^{[1]}$ 根据太阳黑 子的形态定义了黑子的 McIntosh分型. 基于活动区 磁场观测数据, 一系列刻画活动区磁场偏离势场程 度的物理量和活动区磁场复杂性的物理参量被提 出 $^{[2 \sim 7]}$, 例如, 磁场梯度、中性线长度等参量. 活动区
磁场拓扑结构被认为与太阳耀斑的发生密切相关 ${ }^{[8]}$, 活动区流场信息 ${ }^{[9]}$ 和下表面流场参量 ${ }^{[10,11]}$ 也被耀斑 预报模型考虑进来. 活动区的演化信息及其在日面 的位置信息被用来提高耀斑预报的准确度 ${ }^{[12 ~ 14]}$. 然 而, 一些综合的性能比较和评测文章 ${ }^{[9,11,15,16]}$ 显示, 目前提出的针对太阳耀斑的预报参量的预报能力非 常有限.

许多统计和机器学习方法都被用来建立活动区 物理参量与太阳耀斑发生之间联系. 例如, 泊松统计

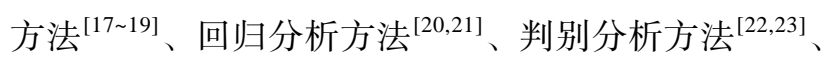

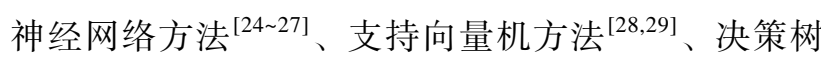
方法 ${ }^{[30]}$ 、贝叶斯网络方法 ${ }^{[31]}$ 、集成学习方法 ${ }^{[32,33]}$ 等. 以太阳活动区的物理参量为基础，这些建模方法均 取得了一定的太阳耀斑预报效果.

近年, 机器学习领域取得了快速的发展, 特别是 以深度学习 ${ }^{[34,35]}$ 为代表的数据建模方法. 与之前的 
机器学习方法不同的是, 深度学习方法能够从原始 观测数据中自动学习特征参量, 并建立预报模型, 而 不再需要特别针对活动区提取特定的物理参量, 该 方法大大降低了建立预报模型的难度, 并在语音识 别 ${ }^{[36]}$ 、自然语言处理 ${ }^{[37]}$ 、目标识别和分类 ${ }^{[38]}$ 等领域 取得了巨大的进展.

本文以太阳活动区光球磁场观测数据为基础, 利用深度学习方法自动提取活动区的特征并建立太 阳耀斑预报模型. 同时, 以活动区的物理参量为基 础, 利用传统的神经网络方法建立了太阳耀斑预报 模型, 通过比较两个模型的性能, 验证了新模型的有 效性.

\section{1 方法}

到目前为止, 太阳耀斑爆发的物理机制并不完 全清晰, 太阳耀斑预报本质上还是以活动区特征为 基础的概率预报. 机器学习方法能够更好地找出太 阳活动区物理参量与太阳耀斑爆发之间的关系. 然 而, 对传统的机器学习算法而言, 太阳活动区的特征 提取问题成为整个系统的瓶颈. 虽然太阳物理学家 已经提出一系列活动区物理特征参量, 但是它们的 预报能力有限. 同时, 在机器学习领域发展出深度学 习方法, 该方法能够实现从原始观测数据中自动提 取特征, 并建立预报模型. 其中卷积神经网络常常用 来处理图像数据. 一个典型的卷积神经网络由如下 4 部分组成:

(1) 卷积层. 卷积层计算输人数据和指定滤波器 的卷积计算, 并将卷积的结果作为输出. 卷积层常用 来提取对象的低层特征. (2) 池化层. 池化层用于计 算某一指定区域的统计特性(例如平均值、最大值等), 池化层计算输人数据在指定范围的统计参量, 并将 统计结果作为输出. 池化层通常用于降低数据的维 度, 防止模型过拟合. 本文使用最大值池化方法. (3) 归一化层. 归一化层实现了从输人到输出的非线性 变换. 该层用于在模型中增加非线性特征. 常用的归 一化函数有 $\mathrm{S}$ 形激活函数 $\left(f(x)=\frac{1}{1+\mathrm{e}^{-x}}\right)$ 和 $\mathrm{ReLu}$ (Rectified Linear Units) $(f(x)=\max (0, x))$ 激活函数. 由于 ReLu函数具有更快的模型收玫能力, 本文选 $\operatorname{ReLu}$ 函数作为归一化函数. (4) 全连接层. 全连接层 中的每个神经元与前一层的所有神经元相连. 通常 全连接层是卷积神经网络最后几层的结构, 前面几
层的输出在全连接层中进行高阶段的推理和计算, 并给出模型最终的输出结果.

综上所述，一个卷积神经网络由若干层卷积层、 池化层、归一化层和全连接层组成. 模型设计者给出 卷积神经网络的结构, 网络中的权值由观测数据确 定. 确定网络权值的过程被称为学习或训练. 选择随 机梯度下降法 ${ }^{[39]}$ 训练提出的卷积神经网络. 在模型 的训练过程中，使用优化算法调整网络的权值，达到 最小化训练误差的目的. 训练的最终目的是为了使 模型在新数据上具有良好的预测能力. 为了检测模 型的训练是否达到既定的目标, 使用测试数据对模 型的性能进行测试.

\section{2 数据}

为了训练给定结构的卷积神经网络, 并测试预 报模型的性能, 需要长期一致的太阳活动区磁场观 测数据形成模型的训练和测试数据. 与 SDO(Solar Dynamics Observatory) 卫 星 HMI(Helioseismic and Magnetic Imager)数据相比, SOHO(Solar and Heliospheric Observatory)卫星MDI(Michelson DopplerImager)数据累积了更多的太阳活动区观测数据. 而且 基于 MDI数据建立的模型可以通过模型微调 (Finetune)的方法应用于HMI数据中. 因此本文选自 MDI数据建立太阳耀斑的预报模型.

Mason $^{[40]}$ 整理了从1996年4月到2008年12月共13 年间位于日面中心 $30^{\circ}$ 范围内的具有 NOAA(National Oceanic and Atmospheric Administration)编号的活动 区列表 (http://soi.stanford.edu/data/tables/). 日面 30 范围内的活动区观测图像的投影效应可以被忽略. 对列表中的活动区, Mason计算了 5 个物理参量：(1) 无符号磁场通量的加和; (2) 磁场梯度加权的中性线 长度; (3) 磁场中性线上的平均磁场梯度值; (4) 有效 分隔距离; (5) 磁场中性线长度. 使用列表中整理出 的所有活动区数据进行模型的训练和测试.

太阳耀斑数据来源于NGDC(National Geophysical Data Center)整理的数据列表(ftp://ftp.ngdc.noaa.gov/ STP/space-weather/solar-data/solar-features/solar-flare s/x-rays/goes/xrs/). 根据太阳软 X射线流量, 太阳耀 斑可以分为 $\mathrm{C}$ 级、 $\mathrm{M}$ 级和 $\mathrm{X}$ 级. 将一段时间内的耀斑流 量总和作为耀斑重要程度的指标:

$$
I_{\text {tot }}=\sum c+10 \times \sum m+100 \times \sum x,
$$

其中, $c, m, x$ 分别为 $\mathrm{C}$ 级耀斑、 $\mathrm{M}$ 级耀斑、 $\mathrm{X}$ 级耀斑所 
对应的系数.

如果一个活动区, 在 48 小时内观测到的所有大 于 $\mathrm{C}$ 级的耀斑的 $I_{\mathrm{tot}}$ 值超过 10 (综合影响等价于 $\mathrm{M} 1.0$ 级 别的耀斑), 则认为该活动区为耀斑样本, 否则认为 该活动区为无耀斑样本. 我们的数据集总共包含 9993 个耀斑样本和 60085 个无耀斑样本. 数据集被分 成训练数据和测试数据, 训练数据用于建立预报模 型, 测试数据用于评价模型的性能. 为了保证模型测 试的客观性, 在训练数据中出现的数据不会在测试 数据中出现.

\section{3 结果}

使用伯克利视觉和学习中心 (Berkeley Vision and Learning Center)开发的深度学习框架 $\mathrm{Caffe}^{[41]}$ 建 立太阳耀斑卷积神经网络预报模型. 该模型的结构 如图 1(a)所示. 该模型以太阳活动区光球视向磁场作 为模型的输人, 接下来是一个卷积层 $(100$ 个 $7 \times 7$ 的滤 波器) 和一个最大值池化层 $(3 \times 3)$, 然后是另一个卷积 层 $(150$ 个 $7 \times 7$ 的滤波器) 和最大值池化层 $(3 \times 3)$, 继续 连接一个全连接层 $(200 \times 20 \times 2$ 个节点 $)$, 最后模型的两 个输出分别代表预测未来 48 小时是否有耀斑发生.

为了比较卷积神经网络的太阳耀斑预报模型的
性能, 基于相同的数据集, 利用传统的神经网建立另 外一个太阳耀斑预报模型，该模型的结构如图1(b)所 示. 该方法首先从输人的活动区视向磁图中计算 5 个 物理参量(无符号磁场通量的加和; 磁场梯度加权的 中性线长度; 磁场中性线上的平均磁场梯度值; 有 效分隔距离; 磁场中性线长度), 以这 5 个物理参量为 输人, 连接一个与卷积神经网络相同的全连接层 $(200 \times 20 \times 2$ 个节点 $)$, 模型的两个输出与卷积神经网络 的输出相同.

我们的模型有两类输出(耀斑或无耀斑), 因此模 型的测试结果会出现4种情况, 分别标识为 TP, TN, FP, $\mathrm{FN}$. 其中 TP定义为例样本预报为正类的数目, $\mathrm{TN}$ 为对 负类样本预报为负类的数目; $\mathrm{FP}$ 为对负类样本预报为 正类的数目; $\mathrm{FN}$ 为对正类样本预报为负类的数目.

根据这4种情况，可以定义如下 5 个指标反映模 型的测试性能:

$$
\begin{gathered}
\text { TPrate }=\frac{\mathrm{TP}}{\mathrm{TP}+\mathrm{FN}}, \\
\text { TNrate }=\frac{\mathrm{TN}}{\mathrm{TN}+\mathrm{FP}}, \\
\text { Acc }=\frac{\mathrm{TP}+\mathrm{TN}}{\mathrm{TP}+\mathrm{FN}+\mathrm{TN}+\mathrm{FP}},
\end{gathered}
$$
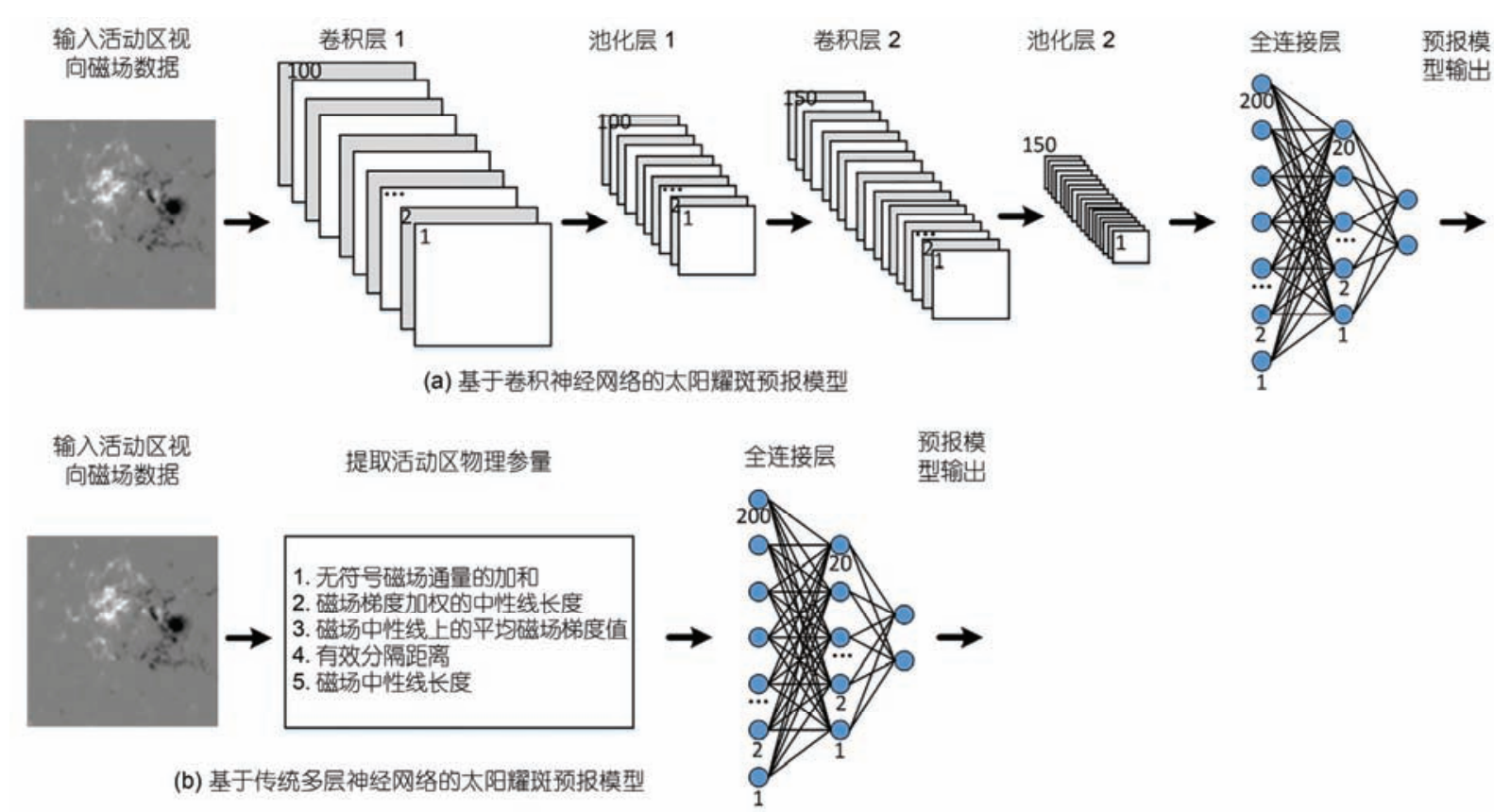

图 1 (网络版彩色)基于卷积神经网络(a)和传统神经网络(b)的太阳耀斑预报模型

Figure 1 (Color online) Structures of two solar flare forecasting models. (a) The structure of convolutional neural network for solar flare forecasting; (b) the structure of traditional multilayer neural networks for solar flare forecasting 


$$
\mathrm{HSS}=\frac{\frac{\mathrm{TP}+\mathrm{TN}}{\mathrm{TP}+\mathrm{FN}+\mathrm{TN}+\mathrm{FP}}-\frac{(\mathrm{TP}+\mathrm{FN})(\mathrm{TP}+\mathrm{FP})+(\mathrm{TN}+\mathrm{FP})(\mathrm{TN}+\mathrm{FP})}{(\mathrm{TP}+\mathrm{FN}+\mathrm{TN}+\mathrm{FP})^{2}}}{1-\frac{(\mathrm{TP}+\mathrm{FN})(\mathrm{TP}+\mathrm{FP})+(\mathrm{TN}+\mathrm{FP})(\mathrm{TN}+\mathrm{FP})}{(\mathrm{TP}+\mathrm{FN}+\mathrm{TN}+\mathrm{FP})^{2}}},
$$

$$
\mathrm{TSS}=\frac{\mathrm{TP}}{\mathrm{TP}+\mathrm{FN}}-\frac{\mathrm{FP}}{\mathrm{FP}+\mathrm{TN}} .
$$

上述 5 个指标中, TPrate反映了耀斑样本的报准 率, TNrate反映了无耀斑样本的报准率, Acc反映了两 类样本的综合报准率, HSS反映了预报模型给出的预 报相较于随机预报的改善程度, TSS 计算了耀斑样本 报准率和误报率的差值.

我们的数据集从1996年4月到2008年12月共包含 70078 个样本. 其中从 1996 年 4 月到 2004 年 3 月共 60000 个样本被作为训练数据集, 余下的样本被作为 测试数据集. 利用训练数据集建立太阳耀斑预报模 型, 利用测试数据集测试模型的性能. 为了表述方 便, 把基于卷积神经网络方法建立的太阳耀斑预报 模型称为深度模型, 把基于全连接神经网络方法建 立的太阳耀斑预报模型称为传统模型. 深度模型的 $\mathrm{TP}$ 值为 785 , FP值为 1859 , FN值为 $441, \mathrm{TN}$ 值为 6993 . 传统模型的 TP值为 $740, \mathrm{FP}$ 值为 $2044, \mathrm{FN}$ 值为 $486, \mathrm{TN}$ 值为 6808. 两类模型的测试指标如表 1 所示.

由测试结果发现深度模型的太阳耀斑预报性能 比传统模型的预报性能略好. 深度模型直接以原始 的活动区视向磁场观测数据为输人, 不需要计算复 杂的物理参量, 并且能够取得更好的预报结果, 因此 基于深度学习方法的太阳耀斑预报模型具有更好的 实用性.
表 1 深度模型和传统模型在测试数据集上的测试指标对比

Table 1 Performance evaluation measures of two solar flare forecasting models

\begin{tabular}{lcc}
\hline 测试参数 & 深度模型 & 传统模型 \\
\hline TP rate & $64 \%$ & $60 \%$ \\
TN rate & $79 \%$ & $77 \%$ \\
Acc & $77 \%$ & $75 \%$ \\
HSS & 0.28 & 0.24 \\
TSS & 0.43 & 0.37 \\
\hline
\end{tabular}

\section{4 结论}

基于卷积神经网络方法, 建立了一个太阳耀斑 预报模型. 与传统的机器学习方法相比, 该模型不用 从太阳活动区光球磁场中提取物理参量, 而是直接 以活动区磁场观测数据为输人, 自动提取活动区的 特征并建立预报模型. 与需要提取人工定义的活动 区物理参量的传统机器学习方法相比, 该预报模型 取得了更好的预报性能. 在这个工作中, 验证了深度 学习方法自动特征提取能力在太阳耀斑预报问题中 的有效性. 在今后的工作中, 将使用太阳活动区的矢 量磁场数据或极紫外的多波段观测数据, 利用深度 学习方法的特征学习能力, 抽取活动区的特征并建 立预报模型. 该方法展现出更好的预报能力, 并具有 更强的实用性，值得继续开展相关研究工作.

\section{参考文献}

1 McIntosh P S. The classification of sunspot groups. Solar Phys, 1990, 125: 251-267

2 Falconer D A, Moore R L, Gary G A. A measure from line of sight magnetograms for prediction of coronal mass ejections. J Geophys Res: Space Phys, 2003, 108: 1380

3 Leka K D, Barnes G. Photospheric magnetic field properties of flaring versus flare-quiet active regions. I. Data, general approach, and sample results. Astrophys J, 2003, 595: 1277-1295

4 Cui Y M, Li R, Zhang L Y, et al. Correlation between solar flare productivity and photospheric magnetic field properties 1. Maximum horizontal gradient, length of neutral line, number of singular points. Sol Phys, 2006, 237: 45-59

5 Georgoulis M K, Rust D M. Quantitative forecasting of major solar flares. Astrophys J Lett, 2007, 661: L109

6 Schrijver C J. A characteristic magnetic field pattern associated with all major solar flares and its use in flare forecasting. Astrophys J Lett, 2007, 655: L117

7 Yang X, Zhang H Q, Gao Y, et al. A statistical study on photospheric magnetic nonpotentiality of active regions and its relationship with flares during solar cycles 22-23. Solar Phys, 2012, 280: 165-181 
8 Barnes G, Leka K D. Photospheric magnetic field properties of flaring versus flare-quiet active regions. III. Magnetic charge topology models. Astrophys J, 2006, 646: 1303

9 Komm R, Ferguson R, Hill F, et al. Subsurface vorticity of flaring versus flare-quiet active regions. Solar Phys, 2011, 268: 389-406

10 Gao Y, Zhao J, Zhang H. A study of connections between solar flares and subsurface flow fields of active regions. Solar Phys, 2014, 289: 493-502

11 Welsch B T, Li Y, Schuck P W, et al. What is the relationship between photospheric flow fields and solar flare? Astrophys J, 2009, 705: 821

12 Korss M B, Ludmny A, Erdlyi R, et al. Flare predictability basedon sunspot group evolution. Astrophys J Lett, 2015, 802: L21

13 Yu D R, Huang X, Hu Q, et al. Short-term solar flare prediction using multi-resolution predictors. Astrophys J, 2010, 709: 321-326

14 Huang X, Zhang L, Wang H, et al. Improving the performance of solar flare prediction using active longitudes information. Astron Astrophys, 2013, 549: 419

15 Barnes G, Leka K D. Evaluating the preformance of solar flare forecasting methods. Astrophys J, 2008, 688: L107-L110

16 Leka K D, Branes G. Photospheric magnetic field properties of flaring versus flare-quiet active regions. IV. A Statistically significant sample. Astrophys J, 2007, 656: 1173-1186

17 Gallagher P T, Moon Y, Wang H M. Active-region monitoring and flare forecasting I. Data processing and first results. Sol Phys, 2002, 209: 171-183

18 Wheatland M S. A statistical solar flare forecast method. Space Weather, 2005, 3: 07003

19 Bloomfield D S, Higgins P A, McAteer R T J, et al. Toward reliable enchmarking of solar flare forecasting methods. Astrophys J Lett, 2012, 747: L41

20 Bornmann P L, Shaw D. Flare rates and the McIntosh active-region classifications. Solar Phys, 1994, 150: 127-146

21 Song H, Tan C, Jing J, et al. Statistical assessment of photospheric magnetic features in imminent solar flare predictions. Solar Phys, 2009, 254: 101-125

22 Leka K D, Barnes G. Photospheric magnetic field properties of flaring versus flare-quiet active regions. II. Discriminant analysis. Astrophys J, 2003, 585: 1296-1306

23 Barnes G, Leka K D, Schumer E A, et al. Probabilistic forecasting of solar flares from vector magnetogram data. Space Weather, 2007, 5: S09002

24 Qahwaji R, Colak T. Automatic short-term solar flare prediction using machine learning and sunspot associations. Sol Phys, 2007, 241: 195-211

25 Wang H N, Cui Y M, Li R, et al. Solar flare forecasting model supported with artificial neural network techniques. ASR, 2008, 42: $1464-1468$

26 Colak T, Qahwaji R. Automated Solar Activity Prediction: A hybrid computer platform using machine learning and solar imaging for automated prediction of solar flares. Space Weather, 2009, 7: S06001

27 Ahmed O W, Qahwaji R, Colak T, et al. Solar flare prediction using advanced feature extraction, machine Learning, and feature selection. Solar Phys, 2013, 283: 157-175

28 Yuan Y, Shih F Y, Jing J, et al. Automated flare forecasting using a statistical learning technique. Res Astron Astrophys, 2010, 10: 785

29 Bobra M G, Couvidat S. Solar flare prediction using SDO/HMI vector magnetic field data with a machine-learning algorithm. Astrophys J, 2015, 798: 135

30 Yu D R, Huang X, Wang H N, et al. Short-term solar flare prediction using a sequential supervised learning method. Sol Phys, 2009, 255: 91

31 Yu D, Huang X, Wang H, et al. Short-term solar flare level prediction using a bayesian network approach. Astrophys J, 2010, $710: 869$

32 Huang X, Yu D, Hu Q, et al. Short-term solar flare prediction using predictor teams. Sol Phys, 2010, 263: 175-184

33 Guerra J A, Pulkkinen A, Uritsky V M. Ensemble forecasting of major solar flares: First results. Space Weather, 2015, 13: 626-642

34 Hinton G E, Salakhutdinov R. Reducing the dimensionality of data with neural networks. Science, 2006, 313: 504-507

35 LeCun Y, Bengio Y, Hinton G. Deep learning. Nature, 2015, 521: 436-444

36 Deng L, Yu D, Hinton G E. Deep Learning for Speech Recognition and Related Applications. NIPS Workshop, 2009

37 Collobert R, Weston J, Bottou L, et al. Natural language processing (almost) from scratch. J Mach Learn Res, 2011, 12: 2493-2537

38 Krizhevsky A, Sutskever I, Hinton G E. Imagenet classification with deep convolutional neural networks. NIPS, 2012: 1097-1105

39 LeCun Y, Bottou L, Bengio Y, et al. Gradient-based learning applied to document recognition. In: Proceedings of the IEEE, 1998, 86: $2278-2324$

40 Mason J P, Hoeksema J T. Testing automated solar flare forecasting with 13 years of Michelson Doppler imager magnetograms. Astrophys J, 2010, 723: 634

41 Jia Y, Shelhamer E, Donahue J, et al. Caffe: Convolutional architecture for fast feature embedding. In: Proceedings of the 22nd ACM international conference on Multimedia, 2014. 675-678 


\title{
Solar flare forecasting model based on automatic feature extraction
}

\author{
LI Rong ${ }^{1}$, ZHU Jie ${ }^{1}$, HUANG Xin ${ }^{2} \&$ CUI YanMei ${ }^{3}$ \\ ${ }^{1}$ Beijing WuZi University, Beijing 101149, China; \\ ${ }^{2}$ National Astronomical Observatories, Chinese Academy of Sciences, Beijing 100012, China; \\ ${ }^{3}$ Center for Space Science and Applied Research, Chinese Academy of Sciences, Beijing 100090, China
}

Solar flares are outbursts in the solar atmosphere resulting from sudden release of magnetic energy. The associated high energy particles and radiation threaten the safety of astronauts, reduce the lifetime of satellites, disturb the radio communications and degrade the precision of Global Positioning System. The radiation reaches the Earth about 8 min, and high energy particles take about $30 \mathrm{~min}$ to reach the earth after a solar flare. So solar flare forecasting is critical for providing enough time to respond to the space weather effects. Up to now, many statistical and machine learning methods are used to build a solar flare forecasting model. A machine learning based solar flare forecasting model normally requires solar physicists to design a feature extractor which can transform the observational images of active regions into physical features, and then the relationships between the features and the solar flares are discovered by the machine leaning algorithm. The priori knowledge of the solar physicists is added into the solar flare forecasting model by designing the feature extractor. For most of the machine learning methods, the hard part is what kinds of features should be extracted from the raw data. Considerable solar physicists spend a lot of time extracting the physical parameters from observational data of active regions. Deep learning method, which removes this manual step, can automatically discover useful patterns from the raw data and build a forecasting model. Instead of designing the feature extractor by solar physicists, we learn a solar flare forecasting model from magnetogram pixels by using deep learning method. We use Caffe, which is a deep learning framework developed by the Berkeley Vision and Learning Center, to build a convolutional neural network for solar flare forecasting. In order to compare the performance of proposed forecasting model with that of the forecasting model built by using traditional machine learning method, we build the other solar flare forecasting model based on the same dataset. In the traditional forecasting model, physical parameters designed by the solar physicist are extracted from the magnetogram of active regions, and then these parameters are fed to the forecasting model. We build a traditional forecasting model by multilayer neural networks. For convenience, the solar flare forecasting model built by using deep learning method is called deep model, and the solar flare forecasting model built by using the traditional multilayer neutral networks is called traditional model. Using the same testing data, the performances of the deep model and the traditional model are evaluated and compared. We find that the performance of the deep model is little better than that of the traditional model. The results confirm that the deep model can automatically learn solar flare forecasting features from magnetograms of active regions. This is our first time to automatically learn the forecasting patterns for solar flares from raw data instead of designing the physical patterns by solar physicists. The effectiveness of the deep learning method for the solar flare forecasting is validated. In the future, the deep learning method can be used to automatically discover the solar flare forecasting patterns from the vector magnetograms or the extreme ultraviolet images of active regions.

solar flares, solar active regions, magnetic feature, machine learning

doi: 10.1360/N972016-01055 